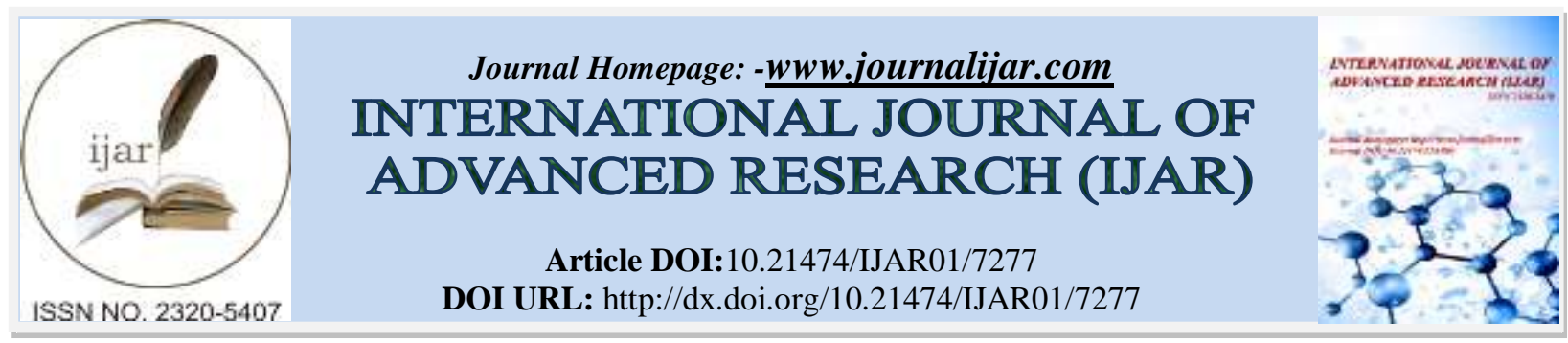

RESEARCH ARTICLE

\title{
FORMULATION AND EVALUATION OF IBUPROFEN TABLET USING ISOLATED STARCH FROM UNRIPE PAPAYA FRUITS AS A DISINTEGRANT.
}

Sunitasonartiya and Dr. Shikhaagrawal.

Department Of Pharmaceutics, Swami Vivekanand College Of Pharmacy Indore.

\section{Manuscript Info}

Manuscript History

Received: 13 April 2018

Final Accepted: 15 May 2018

Published: June 2018

Keywords:-

Papaya starch, corn starch Ibuprofen drug, disintegration properties.

\begin{abstract}
The main objective of this research was to introduce and evaluate the disintegrate property of natural excipient like starch from unripe fruits of Papaya when used in tablet formulation. Pharmaceutical excipients developed from natural sources are economic. The unripe fruit of Papaya has high level of starch content and hence used as a raw material for starch isolation. Starch was isolated from green unripe papaya fruits using $0.5 \mathrm{~N} \mathrm{NaOH}$ as Lye solution. Isolated starch was evaluated and used as a disintegrant in formulation of tablet using ibuprofen as model drug by wet granulation method. Studies indicate that starch so obtained is qualitatively and quantative comparable to corn starch. The disintegration time of formulated tablet was evaluated as per Indian Pharmacopoeia and was compare with marketed tablets. Result from various evaluations suggested characteristics of papaya starch that could be used as disintegrant in formulation.
\end{abstract}

Copy Right, IJAR, 2018,. All rights reserved.

\section{Introduction:-}

Starch is one of the most widely used excipient as filler, binder, and disintegrant in the manufacture of solid dosage forms. Starch is a relatively cheap raw material with physical and chemical properties that impart multiple uses in pharmaceutical industry like binding agent. Starch can be extracted using different processes, depending on the plant source and use of the starch. Starch from various sources has been widely used for various reasons in pharmaceutical formulations. Besides the yield of isolated starch, in order to make it economically viable, it must be accomplished without any significant modification to the starch granules. Carica papaya Linn. (C.P) (Caricaceae) is a fastgrowing, semi woody tropical herb reaching 3-10 $\mathrm{m}$ in height. The fleshy stem is single, straight and hollow and contains prominent leaf scars. Papaya exhibits strong apical dominance rarely branching unless the apical meristem is removed, or damaged. Carica papaya contains many biologically active compounds. Since, each part of papaya tree possesses economic value; it is grown on commercial scale. Unripe pulp of Carica papaya can be ranked as carbohydrate rich fruit due to its high carbohydrate and starch contents. Unripe Carica papaya fruit contains about $45 \%$ of starch. Starch is used as multifunctional excipients in the field of pharmaceutical sciences. Swelling property of the starch is responsible for its disintegration activity. Disintegrating agents are the hydrophilic substances which when come in contact with saliva or gastric fluid absorb water, swell and cause disintegration of tablets. Although Corn starch is one of the most widely used starches in pharmaceutical formulations, starches from other botanical sources have shown difference in functional properties such as gelling, swelling and water binding capacity which influence their capacity to function effectively as binding and disintegrating agent. Due to their effect as powerful disintegrant, starches have been found useful in preparation of insoluble drug substances. In the present study starch was isolated from the unripe papaya pulp and the isolated starch was used as disintegrant for the preparation of 
tablets using Ibuprofen as a model drug. Wet granulation method was used for the preparation of tablets. The tablets were then evaluated as per Indian Pharmacopoeia and compared with marketed tablets.

\section{Materials And Methods:-}

Unripe papaya was obtained from local market and starch was isolated in laboratory. Ibuprofen drug was found Fisher Scientific, Corn starch was found central laboratory and all other chemicals were of analytical grade which were obtained from Fisher scientific, SD fine laboratory.

\section{Isolation of Starch:-}

Extraction of starch from unripe papaya was carried by alkaline extraction method using sodium hydroxide as Lye solution. The pulp of unripe papaya was isolated and dried, powdered and mixed with $0.5 \mathrm{~N} \mathrm{NaOH}$ solution to prepare a slurry in ratio 1:3 (Papaya: Lye solution). The slurry was held for 3 hours, then diluted with water in ratio 1:5 (Slurry: Water). The mass was then strained through muslin cloth and washed with saline solution several times to remove soluble substances, sugar and mucilage present. The mass obtained was then washed repeatedly until the supernatant solution was clear. This residue was further filtered and centrifuged at $5000 \mathrm{rpm}$ for $45 \mathrm{~min}$. The sedimented starch was collected and washed with ethanol followed by water until the $\mathrm{pH}$ was neutral. It was then sieved, dried at room temperature and milled to fine powder.

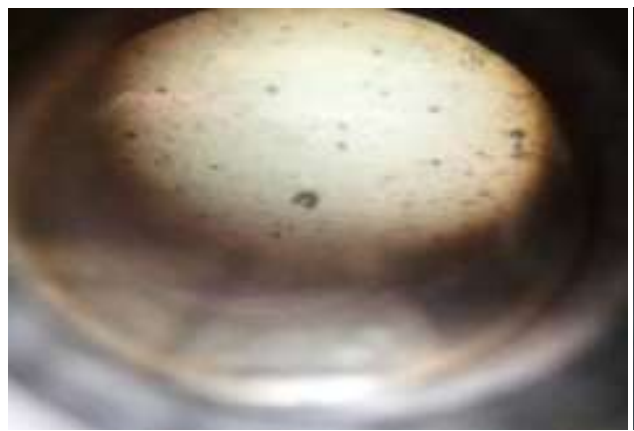

Fig 1:-A Corn Starch

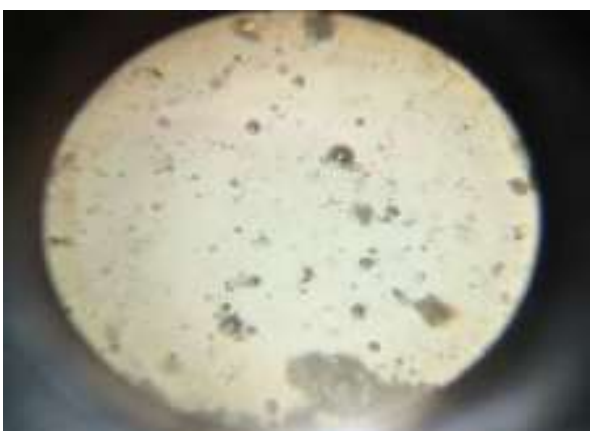

Fig 2:-B Papaya Starch

\section{Pharmaceutical Characterization Of Starch:-}

Identification Test (Iodine Test):-

One $\mathrm{g}$ of papaya starch and corn starch was boiled with $50 \mathrm{ml}$ of water separately. After cooling to $1 \mathrm{ml}$ of the mucilage, 2 drops of $0.1 \mathrm{~N}$ iodine solutions were added and the color change was noted. The result is shown in table. No. 1

\section{Particle Size Determination (Optical Microscopy):-}

A small amount of starch was mixed with liquid paraffin and mounted onto a microscope slide with a cover slip and examined by polarized Optical microscopy. The mean particle size of samples of starch was determined microscopically with the aid of a calibrated eyepiece. The particle size of each sample dispersed in liquid paraffin was determined. The result is shown in table no. 2, 3 and fig. 1, 2.

\section{Paste Clarity:-}

The clarity (transmittance $\%$ at $650 \mathrm{~nm}$ ) of papaya starch paste was measured. A $1 \%$ aqueous suspension of starch near neutral $\mathrm{pH}$ was heated in a boiling water bath for $30 \mathrm{~min}$ with intermittent shaking. After the suspension was cooled for $1 \mathrm{hr}$ at $25^{\circ} \mathrm{C}$, the light transmittance at $650 \mathrm{~nm}$ was read against blank. The result is shown in table no. 1

\section{Moisture Content:-}

A Three $\mathrm{g}$ weight each of corn and papaya starch was heated at $132^{\circ} \mathrm{C}$ using moisture analyzer and the reading was recorded. The result is shown in table. No. 1

\section{Swelling capacity:-}

The tapped volume occupied by $10 \mathrm{~g}$ of each corn powder and papaya starch $(V d)$ in a 100 ml measuring cylinder was noted. This powder was then dispersed in $85 \mathrm{ml}$ of distilled water and volume was made up to $100 \mathrm{ml}$ with 
distilled water. After $18 \mathrm{hrs}$ of standing, the volume of the sediment, $(V w)$ was estimated and the swelling capacity was determined using the formula; the result is shown in table. No. 1

Swelling capacity $=\mathrm{Vw}-\mathrm{Vd}$

$\mathrm{Vw}=$ is weight of starch

$\mathrm{Vd}=$ is the volume of sediment Starch

Ash Value of starch:-

Total $2 \mathrm{~g}$ quantity of starch was weighed into a silica crucible and incinerated. Determination of ash value was done by measurement of the residue left after complete combustion in a muffle furnace at $550^{\circ} \mathrm{C}$. the result is shown table.no.1

\section{Preformulation studies \\ Melting Point:}

The melting point of the Ibuprofen was found $75^{\circ} \mathrm{C}$ which is same as reported in monogram IP The Result shown

Table no. 4

\section{pH Determination:}

$\mathrm{pH}$ of ibuprofen was found to be 5.7 which is near the range of monograph as per IP The result shown in Table no.4

Partition coefficient

Partition coefficient determination of ibuprofen was done by simple sheking flask method. The result shown in table no 4

\section{Identification of drug by UV\ Visible Spectrophotometer}

The identification of the drug was done by UV Spectrophotometric method. Small amount of drug was dissolved in $0.1 \mathrm{NaoH}$ solutions and the volume was made up to $100 \mathrm{ml}$ to obtain a stock solution of $100 \mu \mathrm{g} / \mathrm{ml}$. The one $\mathrm{ml} \mathrm{of}$ this stock solution was again diluted with $0.1 \mathrm{NaoH}$ up to $10 \mathrm{ml}$ to obtain a solution of $10 \mu \mathrm{g} / \mathrm{ml}$. the resulting solution was scanned between $240 \mathrm{~nm}$ to $300 \mathrm{~nm}$ in double beam UV/Visible Spectrophotometer and higher peak range shown in fig.no.4

\section{IR studies:}

The IR spectra were recorded using infrared spectrophotometer the IR spectrum of pure ibuprofen interested and compared with standard. The IR spectrum is shown in fig. - 6.

\section{Qualitative Solubility:}

It was found that Ibuprofen was soluble in most of the organic solvent and insoluble in water as shown in tablet 6.

\section{Particle size:}

The result of the microscopic evolution for the measurement of particle size of the drug particles are given below in table no. 7

\section{PREPARATION OF TABLETS}

Tablets were prepared by using wet granulation technique. The formula for single tablet per batch required to prepare $500 \mathrm{mg}$ of ibuprofen tablets is given in Table1. Required quantity of drug, binder, disintegrant and diluents were grinded and passed through sieve no \# 40 separately and then mixed uniformly by using water as granulating agent to get a wet dough mass which was screened through sieve no \# 16 to obtain coarse granules and dried at 45 ${ }^{\circ} \mathrm{C}$ for $1 \mathrm{~h}$. The dried granules were then passed through sieve no \# 20 to obtain uniform sized granules. Required quantities of glidant and lubricant was added to the granules and mixed uniformly. The resultant granules were compressed into tablets by using single punch rotary compression machine. To compare the disintegrant property, controlled tablets were prepared using papaya starch as disintegrant agent instead of isolated unripe papaya.40 tablets were prepared for each batch and stored in an air tight container for further studies.

Table No.4 Formulation of Tablet By Wet Granulation

\begin{tabular}{|c|c|c|c|c|c|c|}
\hline Sr.No. & Ingredients & F1 & F2 & F3 & F4 & F5 \\
\hline 1 & Ibuprofen & 200 & 200 & 200 & 200 & 200 \\
\hline 2 & Papaya starch & 10 & 5 & - & - & 2 \\
\hline 3 & Corn starch & - & - & 10 & 5 & - \\
\hline 4 & Polyvinyl & 30 & 30 & 30 & 30 & 30 \\
\hline
\end{tabular}




\begin{tabular}{|c|c|c|c|c|c|c|}
\hline & pyrollidone & & & & & \\
\hline 5 & $\begin{array}{c}\text { Dicalcium } \\
\text { Phosphate }\end{array}$ & 153 & 158 & 153 & 158 & 155 \\
\hline 6 & Magnesium stearate & 2 & 2 & 2 & 2 & 2 \\
\hline 7 & Talc & 5 & 5 & 5 & 5 & 5 \\
\hline
\end{tabular}

\section{Pre-Compressibity Studies:-}

Angle of Repose:

The angle of repose was determined using funnel method. Funnel that can be fit vertically with stand at $6.3 \mathrm{~cm}$. height. The opening end of funnel is closed with thumb until drug is poured. The $5 \mathrm{gm}$ of powder blend was poured into funnel that can be raised vertically until a maximum cone height (h) was obtained. Radius of the heap (r) was measured and the angle of repose $(\Theta)$ was calculated using the formula. the result is shown table no. 8

\section{Bulk Density}

$$
\Theta=\tan ^{-1}(\mathrm{~h} / \mathrm{r})
$$

Apparent bulk density was determined by pouring the $10 \mathrm{gm}$ of powder blend from each formula into $100 \mathrm{ml}$ granulated cylinder. The bulk volume (V) poured power blend from each formula was determined. The bulk density was calculated using the formula. The result is shown in table. No. 8

Where

$$
\mathbf{p}_{\mathrm{b}}=\mathbf{M} / \mathbf{V}
$$

\section{$\rho_{\mathrm{b}}=$ Bulk Density \\ $M$ - Is the weight of powder drug. \\ $\mathrm{V}$ - Is the volume of powder drug.}

\section{Tapped Density:}

Weight Ten g. of powder blends and placed in a measuring cylinder. Measuring cylinder containing known mass $(10 \mathrm{gm})$ of was tapped for 100 time or fixed time. The minimum volume $\left(\mathrm{V}_{\mathrm{t}}\right)$ occupied was measured. The tapped density was calculated using following formula. The result is shown in table.no.9

$$
\rho_{\mathrm{t}}=\mathrm{M} / \mathrm{V}_{\mathrm{t}}
$$

\section{Where}

\section{$\rho_{\mathrm{t}}=$ Tapped Density}

$$
\begin{aligned}
& M \text { - Is the weight of Powder } \\
& V_{t} \text { - Is the volume of Powder }
\end{aligned}
$$

\section{Compressibility Index}

The simplest way for measurement of free flow of powder is compressibility index was determined by this formula.

The result is shown in table. No. 8

Where

$$
\text { C.I. }(\%)=\rho_{\mathrm{t}}-\rho_{\mathrm{b}} \times 100 / \rho_{\mathrm{t}}
$$

\section{C.I = Compressible Index}

$$
\begin{gathered}
\rho_{\mathrm{t}}=\text { Tapped Density } \\
\rho_{\mathrm{b}}=\text { Bulk Density }
\end{gathered}
$$

\section{Hausner Ratio}

It was studied by following formula. The result is shown in Table.no.8

Where

$$
\text { Hausner ratio }=p_{t} / p_{t}
$$

$$
\begin{gathered}
\rho_{\mathrm{t}}-\text { Tapped Density } \\
\rho_{\mathrm{b}}-\text { Bulk Density }
\end{gathered}
$$

\section{POST COMPRESSIBILITY STUDIES Weight Variation Test:}


The weight variation test of the tablet was performed as per I.P. twenty tablets were selected randomly from each batch and weighed individually on electronic balance. The individual weighted is then compared with average weight for the weight variations. 9

\section{Thickness:}

Table thickness of ibuprofen tablet was measured using Vanier calipers.the result is shown in table no.9

\section{Hardness:}

The hardness of the tablets was determined using Monsanto hardness tester. It is expressed in $\mathrm{kg} / \mathrm{cm}^{2}$. The result is shown in table. No.9

\section{Friability Test:}

Friability of the tablet was determined using Roche friability. The friability (f) is given by the formula. The result is shown in table. No.10.

$\% \mathrm{~F}=\left(1-\mathrm{W}_{0} / \mathrm{W}\right) \times 100$

Where,

$$
\% \text { friability of tablets led then } \% \text { is considered acceptable. }
$$

$\mathbf{W}_{\mathbf{0}}$ is weight of the tablet before the test and $\mathbf{W}$ is the weight of the tablet after the test.

\section{Wetting Time:}

A piece of tissue paper folded twice was kept in a Petridis containing $6 \mathrm{ml}$ of purified water. The tablet was placed on the tissue paper and allowed to wet completely. The time required for complete wetting of the tablet was then recorded. the result is shown in table. no.9

\section{In Vitro Disintegration Time:}

Disintegration test was perform using basket- rack assembly from electro lab. Tablet was placed in each of six tubes of the basket and test was performed using water as the immersion fluid maintained at $37 \pm 2$.time for complete disintegration of all six tablets was noted. the result is shown in table.no.10

\section{Drug Content:}

Ten randomly selected tablets were weighed and average weight is calculated, the tablet was powdered in a glass mortar. The weight equivalent to $400 \mathrm{mg}$ of ibuprofen was accurately weighed and transferred into a $100 \mathrm{ml}$ volumetric flask. It was dissolved and made up the volume with phosphate buffer $\mathrm{pH}$ 7.4. Subsequently the solution in volumetric flask was filtered and suitable dilutions were made and analyzed at $221 \mathrm{~nm}$ using UV - Visible spectrophotometer (shimadzu UV-1800). The drug content of each sample was estimated from standard curve of ibuprofen using phosphate buffer $\mathrm{pH}$ 7.4.the result is shown in table.no.9

\section{In-Vitro Drug Release:}

Dissolution was carried out using IP dissolution apparatus I (paddle apparatus). Dissolution of tablets was carried out in 900 ml-dissolution medium. The dissolution medium for Ibuprofen tablet was phosphate buffer $\mathrm{pH}$ 7.4. The temperature of dissolution medium was maintained at $37^{\circ} \mathrm{C} \pm 2^{\circ} \mathrm{C}$. The agitation intensity was $100 \mathrm{rpm}$. The samples of dissolution medium were withdrawn at every interval of $10 \mathrm{~min}$ for $1 \mathrm{hr}$. samples were analyzed spectrophotometrically (UV-1800 Shimadzu) at $221 \mathrm{~nm}$ and the percentage drug release was calculated. The result shown in table.no.11

Result And Dissection:-

Pharmaceutical characterization

Table no.1 Pharmaceutical Characterization of Starch

\begin{tabular}{|c|c|c|c|}
\hline Sr. No. & Characterization of Starch & Papaya Starch & Corn Starch \\
\hline 1 & Iodine test & $+\mathrm{Ve}$ \\
\hline 2 & Paste Clarity & $40 \%$ & $33 \%$ \\
\hline 3 & Average grain size $(\mu)$ & 7.35 & 4.828 \\
\hline 4 & Ash Value $(\%$ w $/ w)$ & $17.2 \pm 0.8$ & $16.12 \pm 0.2$ \\
\hline 5 & Moisture Content & $4.95 \pm 0.2$ & $7.21 \pm 0.3$ \\
\hline 6 & Swelling Capacity & $2.7 \pm 0.87$ & $2.1 \pm 0.55$ \\
\hline
\end{tabular}




\begin{tabular}{|c|c|c|c|}
\hline 7 & Angle Of Repose & $27.40^{\circ} \pm 1.51$ & $25.24^{\circ} \pm 1.32$ \\
\hline 8 & Bulk density $(\mathrm{g} / \mathrm{ml})$ & $0.55 \pm 0.42$ & $0.49 \pm 0.51$ \\
\hline 9 & Tapped density $(\mathrm{g} / \mathrm{ml})$ & $0.71 \pm 0.30$ & $0.65 \pm 0.52$ \\
\hline 10 & Carr'index & $29.09 \pm 1.22$ & $24.61 \pm 1.46$ \\
\hline 11 & Hausner's ratio & $1.29 \pm 0.28$ & $1.32 \pm 0.67$ \\
\hline
\end{tabular}

Starch extracted from Carica papaya had a light yellowish tinge hence bleaching was carried out with ethanol. On dry basis $45.5 \%$ starch was obtained. Grains of Carica papaya starch were found to be smaller in size compared to Corn starch (Fig. 1a) and (Fig. 1b) They were round \& oval in shape not much difference was observed in loss of drying ash value, $\mathrm{pH}$ value of carica papaya starch \& corn starch. The loss on drying \&acidity values was well within official limit. The bulk density, angle of repose \& compressibility index of both starches was comparable. In all the cases the value of angle of repose were $\leq 30^{\circ}$, which indicate that both the starches were free flowing Table. 1 .

\section{Particle size of corn starch}

The result of the microscopic evolution for the measurement of particle size of the drug particles are given below in table

Table no. 2 Particle Size Distribution of Corn Starch

\begin{tabular}{|c|c|c|c|c|c|}
\hline S.No & $\begin{array}{c}\text { Size } \\
\text { Range }\end{array}$ & $\begin{array}{c}\text { Mid point } \\
(\mathbf{M . P})\end{array}$ & $\begin{array}{c}\text { No. of particle } \\
(\mathbf{N})\end{array}$ & $\begin{array}{c}\text { M.P } \times \mathbf{N} \\
(\mathbf{d})\end{array}$ \\
\hline 1 & $0-1$ & 0.5 & 05 & 2.5 & 3.62 \\
\hline 2 & $1-2$ & 1.5 & 11 & 16.5 & 23.92 \\
\hline 3 & $2-3$ & 2.5 & 15 & 637.5 & 91.35 \\
\hline 4 & $2-4$ & 3.5 & 18 & 103.5 & 150.07 \\
\hline 5 & $4-5$ & 4.5 & 23 & 110 & 159.5 \\
\hline 6 & $5-6$ & 5.5 & 28 & & $\sum \mathrm{d}=482.8$ \\
\hline
\end{tabular}

\section{Particle Size Distribution}

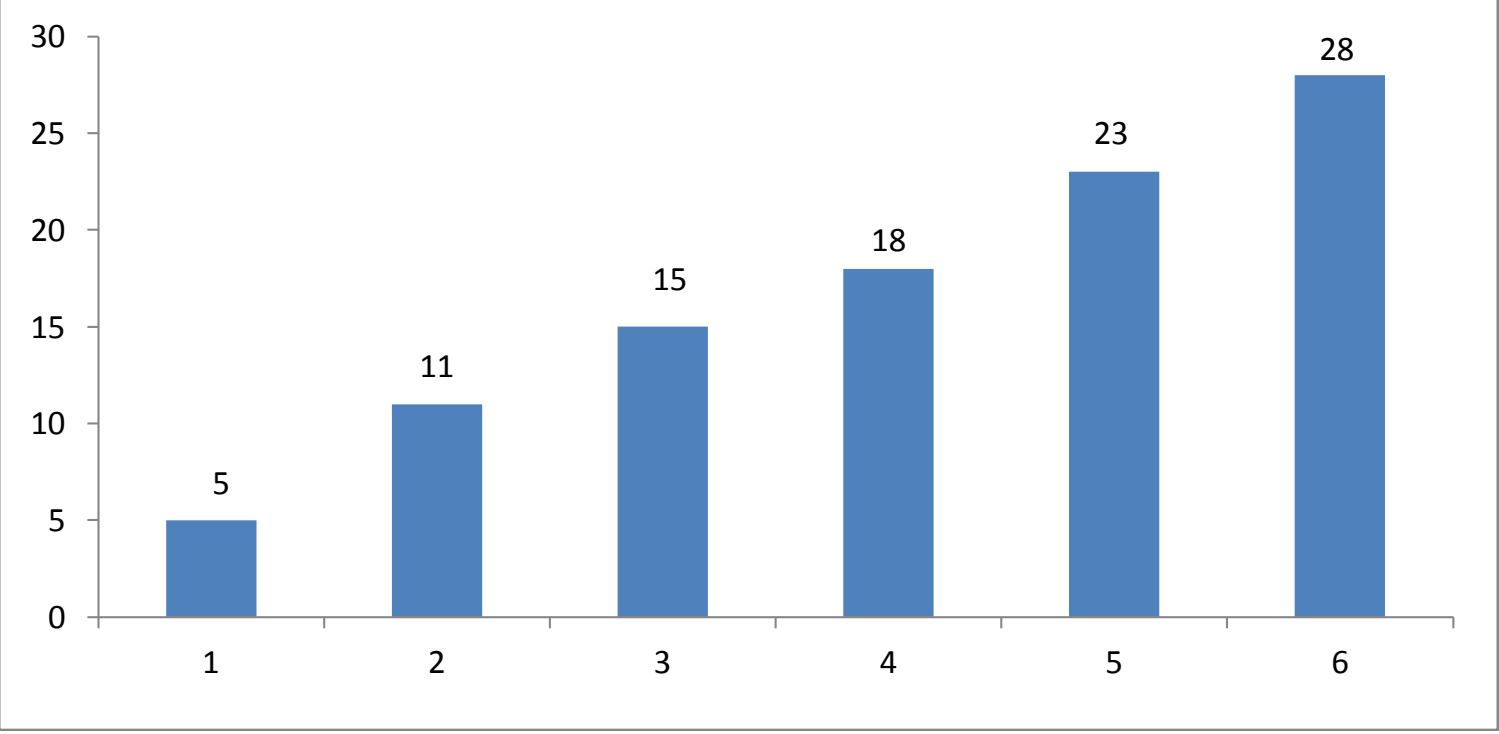

Fig. 2 particle size of corn starch 


\section{Least count $(\mathrm{L} . \mathrm{C})=\mathbf{1 . 4 5}$}

Particle size of Corn starch $=\sum \mathrm{d} \backslash \sum \mathrm{n}$

$$
\begin{aligned}
& =482.8 \backslash 100 \\
& =4.828
\end{aligned}
$$

Particle size was found to be $4.828 \mu \mathrm{m}$. Particle size distribution pattern depicted in fig. show that drug particle are

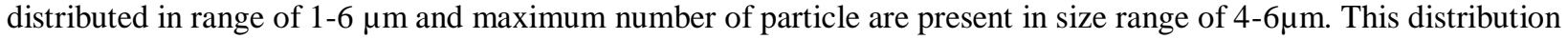
pattern also indicates that the starch is amorphous in nature.

Table no.-3 Particle Size Distribution Of Papaya Starch

\begin{tabular}{|c|c|c|c|c|c|}
\hline S.No & $\begin{array}{c}\text { Size } \\
\text { Range }\end{array}$ & $\begin{array}{c}\text { Mid point } \\
(\mathbf{M . P})\end{array}$ & $\begin{array}{c}\text { No. of particle } \\
(\mathbf{N})\end{array}$ & M.P $\times \mathbf{N}$ & $\begin{array}{c}\text { M.P } \times \mathbf{N} \times \mathbf{L . C} \\
(\mathbf{d})\end{array}$ \\
\hline 1 & $0-1$ & 0.5 & 06 & 3 & 5.88 \\
\hline 2 & $1-2$ & 1.5 & 09 & 13.5 & 26.46 \\
\hline 3 & $2-3$ & 2.5 & 14 & 35 & 68.6 \\
\hline 4 & $2-4$ & 3.5 & 20 & 70 & 137.2 \\
\hline 5 & $4-5$ & 4.5 & 27 & 121.5 & 238.14 \\
\hline 6 & $5-6$ & 5.5 & 24 & 132 & 258.72 \\
\hline & & & $\sum \mathrm{n}=100$ & & $\sum \mathrm{d}=735$ \\
\hline
\end{tabular}

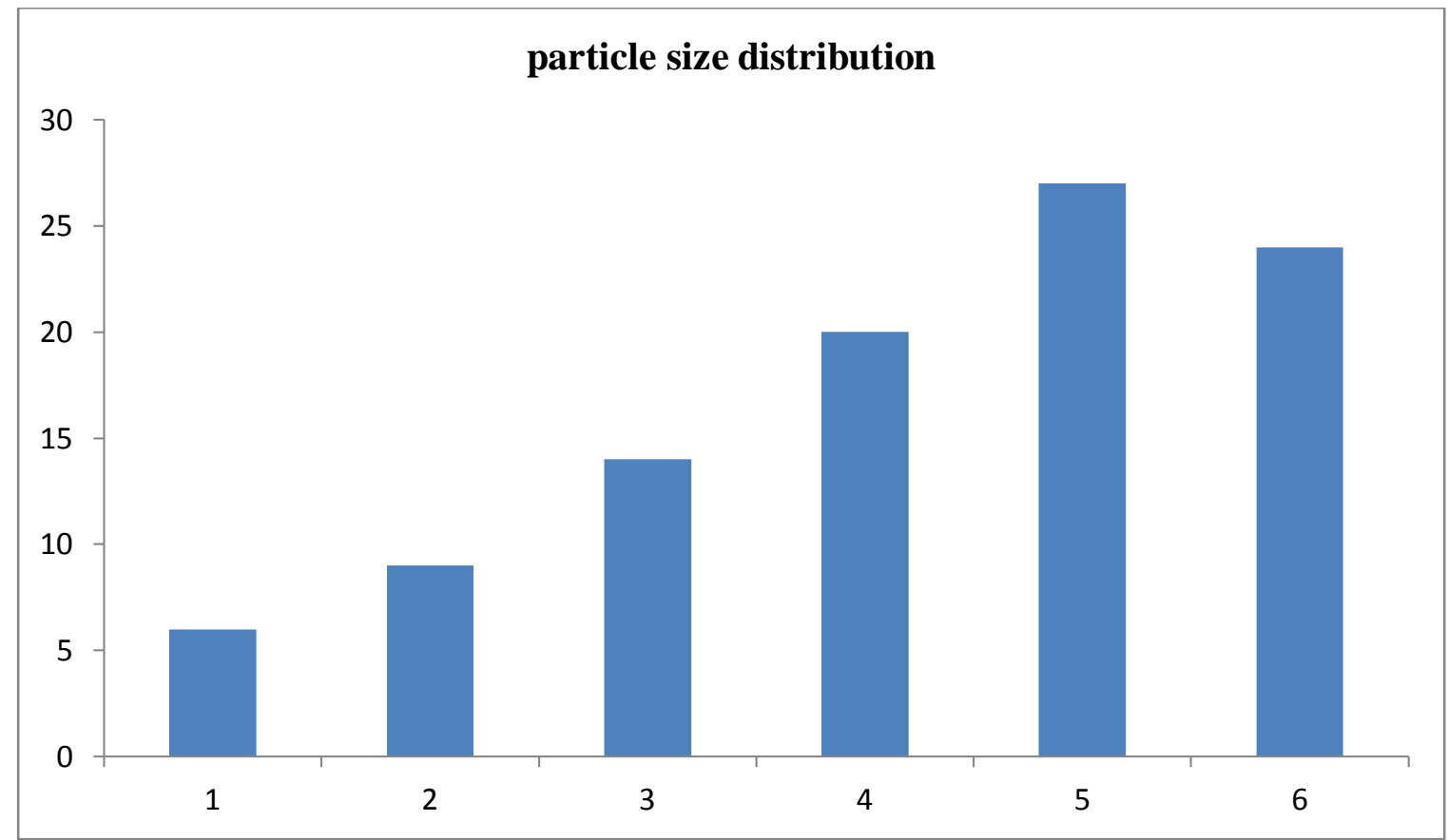

Least count $($ L.C $)=1.96$

Fig. 3 Particle Size Distribution of Papaya Starch

Particle size of Papaya starch $=\sum \mathrm{d} \backslash \sum \mathrm{n}$

$$
\begin{aligned}
& =735 \backslash 100 \\
& =7.35
\end{aligned}
$$

Particle size was found to be $7.35 \mu \mathrm{m}$. Particle size distribution pattern depicted in fig. show that drug particle are

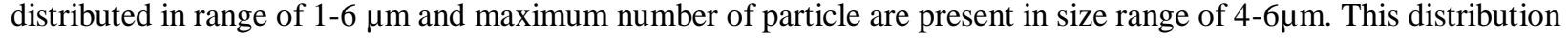
pattern also indicates that the starch is amorphous in nature.

Table no.4 Determination of $\mathrm{pH} \backslash$ melting point $\backslash$ Partition coefficient

\begin{tabular}{|c|c|}
\hline \multicolumn{2}{|c|}{$\mathbf{p H} \backslash$ melting point $\backslash$ partition coefficient } \\
\hline $\mathrm{pH}$ & 5.7 (acidic) \\
\hline Melting Point & $76^{\circ} \mathrm{C}$ (drug is pure) \\
\hline Partition Coefficient & 3.5 (drug is lipophilic) \\
\hline
\end{tabular}




\section{Identification of drug by}

UV/Visible spectrophotometer

UV Spectrophotometric method was used for the analysis of ibuprofen. The UV scan of the drug sample showed highest peak at $256 \mathrm{~nm}$ which is nearby to the standard value. This

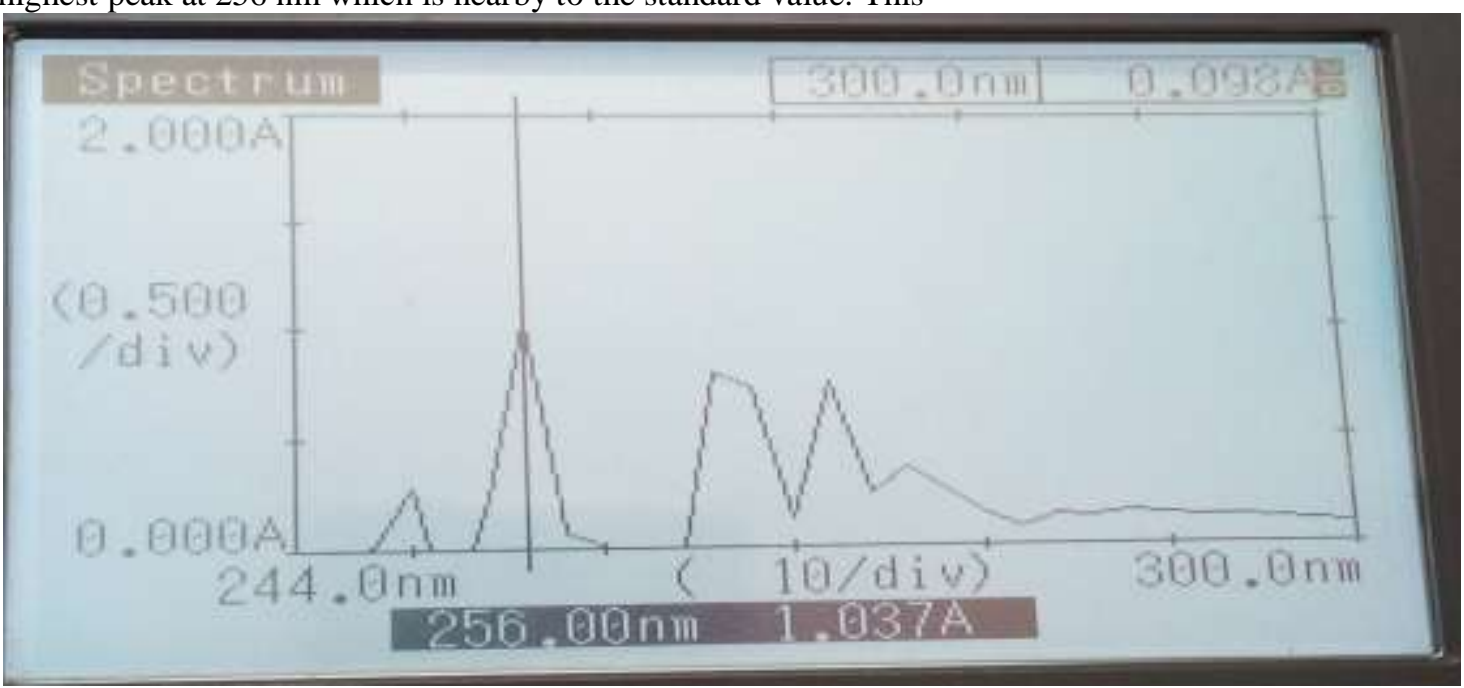

Fig. 4 peak detection $\lambda_{\max }$ for ibuprofen in $0.1 \mathrm{NaoH}$

UV Spectrophotometric method was used for the analysis of ibuprofen. The UV scan of the drug sample showed highest peak at $256 \mathrm{~nm}$ which is nearby to the standard value. This

Standard curve calibration of ibuprofen was prepared in $0.1 \mathrm{NaoH}$ at $256 \mathrm{~nm}$ in UV Spectrophotometer.

Table no. 5 Standard Curve of Ibuprofen In 0.1 NaoH

\begin{tabular}{|c|c|c|}
\hline S.NO. & Concentration $(\boldsymbol{\mu g} / \mathbf{m l})$ & Absorbance \\
\hline 1 & 5 & 0.0754 \\
\hline 2 & 10 & 0.172 \\
\hline 3 & 15 & 0.278 \\
\hline 4 & 20 & 0.384 \\
\hline 5 & 25 & 0.464 \\
\hline 6 & 30 & 0.587 \\
\hline
\end{tabular}

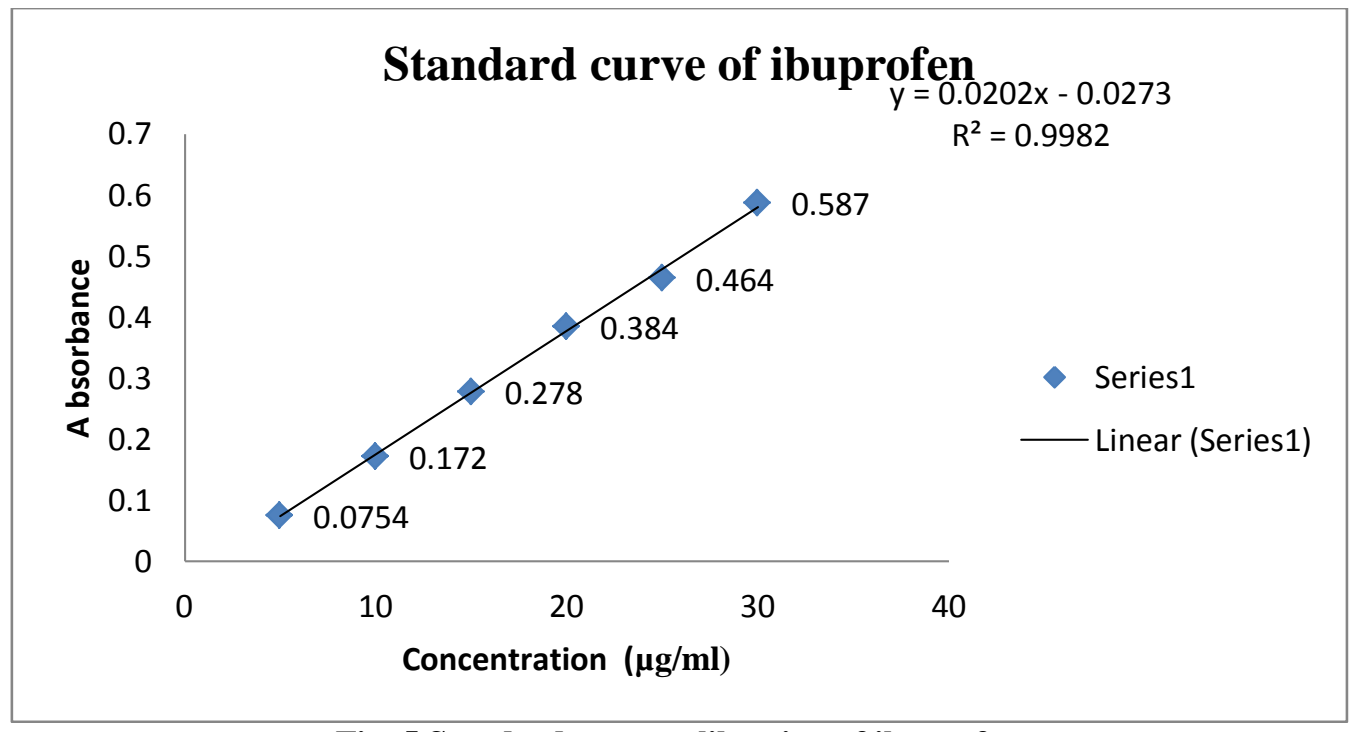

Equation

Fig. 5 Standard curve calibration of ibuprofen

$$
\mathrm{Y}=0.020 \mathrm{x}-0.027
$$




$$
\mathrm{R}^{2}=0.998
$$

$\mathrm{X}=$ concentration in micro gram

For preparation of standard curve, solution of drug sample were prepared in $0.1 \mathrm{NaOH}$ and there were measured at $256 \mathrm{~nm}$ the linearity range were found to $0.1-0.5$.

\section{IR studies:}

The IR spectra were recorded using infrared spectrophotometer .the IR spectrum of pure ibuprofen interested and compared with standard. The IR spectrum is shown in fig. - 4.

\section{IR Spectrum Of Ibuprofen}

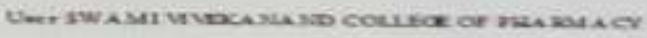

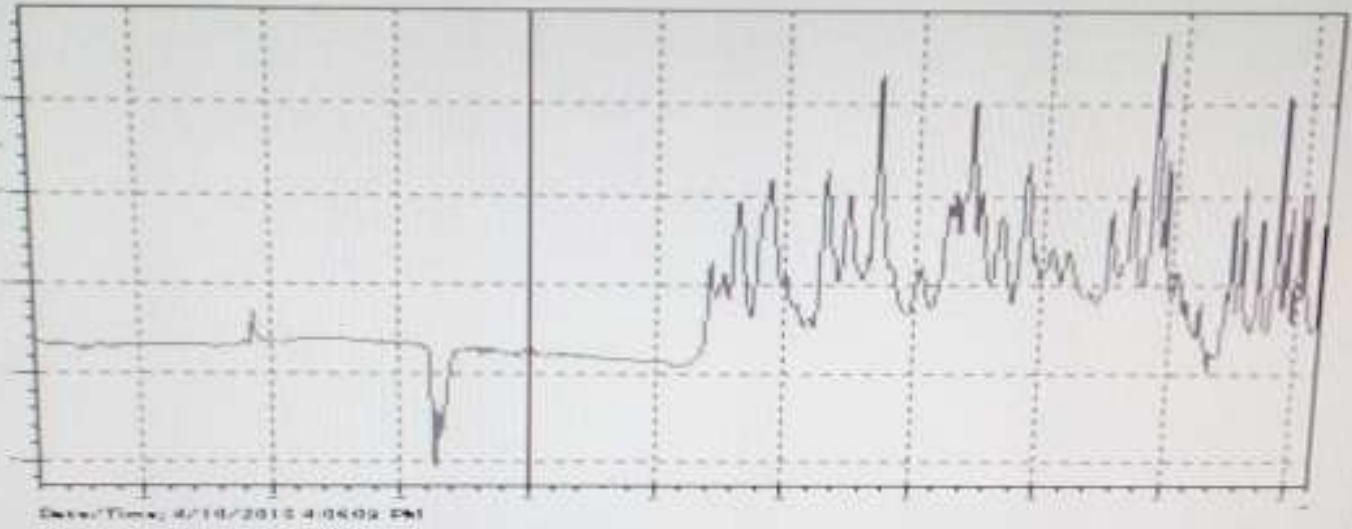

Fig. 6 IR Spectrum Of Ibuprofen Drug

An IR spectrum of drug sample has been interpreted and correlate with standard IR spectrum of ibuprofen. There is no change in functional group of drug sample or same with standard shows that the drug sample is Ibuprofen.

\section{Solubility properties}

Qualitative Solubility:

It was found that Ibuprofen was soluble in most of the organic solvent and insoluble in water as shown in tablet 7.

Table no. 6 Qualitative solubility of Ibuprofen

\begin{tabular}{|c|c|c|}
\hline S.NO. & SOLVENT & SOLUBILITY \\
\hline 1 & Methanol & ++++ \\
\hline 2 & Ethanol & ++++ \\
\hline 3 & Chloroform & +++ \\
\hline 4 & Acetone & ++++ \\
\hline 5 & 7.2 phosphate buffer & +++ \\
\hline 6 & Octanol & ++++ \\
\hline 7 & $0.1 \mathrm{NaoH}$ & ++++ \\
\hline 8 & Water & + \\
\hline
\end{tabular}

$\begin{array}{ll}+ & \text { Insoluble } \\ ++ & \text { Poorly soluble } \\ +++ & \text { Slightly soluble } \\ ++++ & \text { Freely soluble }\end{array}$

Qualitative solubility studies of drug shown in table 4 depicted that the drug is more soluble in organic solvent as compare to hydrophilic solvents so it can be concluded that drug is lipophilic in nature.

\section{Particle size:}

The result of the microscopic evolution for the measurement of particle size of the drug particles are given below in table 
Table no. 7 particle size distribution of ibuprofen

\begin{tabular}{|c|c|c|c|c|c|}
\hline S.No & $\begin{array}{c}\text { Size } \\
\text { Range }\end{array}$ & $\begin{array}{l}\text { Mid point } \\
\text { (M.p) }\end{array}$ & $\begin{array}{c}\text { No. of particle } \\
\text { (N) }\end{array}$ & M.P $\times \mathbf{N}$ & M.P $\times \mathbf{N} \times \mathbf{L} . \mathbf{C}$ \\
\hline 1 & $0-1$ & 0.5 & 04 & 2 & 2.6 \\
\hline 2 & $1-2$ & 1.5 & 09 & 13.5 & 17.55 \\
\hline 3 & $2-3$ & 2.5 & 18 & 45 & 58.5 \\
\hline 4 & $2-4$ & 3.5 & 22 & 77 & 100.01 \\
\hline 5 & $4-5$ & 4.5 & 25 & 112.5 & 135 \\
\hline 6 & $5-6$ & 5.5 & 22 & 121 & 157.3 \\
\hline & & & $\sum \mathrm{n}=100$ & & $\sum \mathrm{d}=470.96$ \\
\hline
\end{tabular}

Least count $(\mathrm{L} . \mathrm{C})=\mathbf{1 . 3}$

Particle size of ibuprofen $=\sum \mathrm{d} \backslash \sum \mathrm{n}$

$$
\begin{aligned}
& =470.96 \backslash 100 \\
& =4.70
\end{aligned}
$$

Particle size was found to be $4.70 \mu \mathrm{m}$. Particle size distribution pattern depicted in fig. show that drug particle are distributed in range of 1-6 $\mu \mathrm{m}$ and maximum number of particle are present in size range of 4-6 $\mu \mathrm{m}$. This distribution pattern also indicates that the drug is crystalline in nature.

Pre-Compression Parameters of formulation

Table no.8 Pre-Compression Parameters of Formulations by wet Granulation Method

\begin{tabular}{|c|c|c|c|c|c|}
\hline $\begin{array}{l}\text { Formulation } \\
\text { code }\end{array}$ & $\begin{array}{l}\text { Bulk } \\
\text { Density } \\
(\mathbf{g m} / \mathbf{m l})\end{array}$ & $\begin{array}{l}\text { Tapped } \\
\text { Density } \\
(\mathbf{g m} / \mathbf{m l})\end{array}$ & $\begin{array}{l}\text { Hausner } \\
\text { Ratio }\end{array}$ & $\begin{array}{l}\text { Compressibility } \\
\text { Index } \\
(\boldsymbol{\%})\end{array}$ & $\begin{array}{l}\text { Angle } \\
\text { Repose }\end{array}$ \\
\hline F1 & 0.581 & 0.682 & 1.17 & 14.66 & $27^{\circ} .22^{\prime}$ \\
\hline F2 & 0.579 & 0.652 & 1.12 & 12.26 & $26^{\circ} .92^{\prime}$ \\
\hline F3 & 0.577 & 0.674 & 1.16 & 14.39 & $27^{\circ} .83^{\prime}$ \\
\hline F4 & 0.568 & 0.678 & 1.19 & 16.22 & $24^{\mathrm{o}} .32^{\prime}$ \\
\hline F5 & 0.585 & 0.681 & 1.16 & 14.09 & $23^{\circ} .44^{\prime}$ \\
\hline
\end{tabular}

The Bulk density of all the formulation was within the range of $0.580 \pm 0.003$ to $0.585 \pm 0.005 \mathrm{gm}$. $/ \mathrm{ml}$ and Tapped density was found to be in the range of $0.682 \pm 0.003$ to $0.681 \pm 0.007$ (good flow property). The angle of repose of powder blends of all formulation was found to be in the range of $23^{0} .44^{\prime} \pm 0.002$ to $27^{\circ} .22^{\prime} \pm 0.12$ (good flow property). The calculated Carr's index of all formulation was found to within the range of $14.66 \pm 0.15$ to $14.09 \pm 0.16$ (good flow property).The calculated Hausners ratio of all formulation was found to within the range of $1.17 \pm 0.12$ to $1.16 \pm 0.13$ (good flow property). The values of pre- compression parameters evaluated were within the prescribed limits and indicated good free flowing properties. Evaluation of formulated granules showed significant increase in bulk and tapped density with increase in concentration of starch and the good correlation was observed between the concentrations of disintegrant.

Post-compression evaluation parameter of tablet

Table 9. Post-Compression Parameters of Formulation Prepared By Wet Granulation

\begin{tabular}{|l|l|l|l|l|l|}
\hline \multirow{2}{*}{$\begin{array}{l}\text { Evaluation } \\
\text { parameter }\end{array}$} & \multicolumn{5}{|c|}{ Formulation code } \\
\cline { 2 - 6 } & $\mathbf{F}_{\mathbf{1}}$ & $\mathbf{F}_{\mathbf{2}}$ & $\mathbf{F}_{\mathbf{3}}$ & $\mathbf{F}_{\mathbf{4}}$ & $\mathbf{F}_{\mathbf{5}}$ \\
\hline Thickness(mm) & $4.854 \pm 0.034$ & $4.792 \pm 0.049$ & $4.792 \pm 0.049$ & $4.792 \pm 0.049$ & $4.792 \pm 0.049$ \\
\hline Hardness $\left(\mathrm{kg} / \mathrm{cm}^{2}\right)$ & $3.05 \pm 0.42$ & $3.12 \pm 0.46$ & $3.70 \pm 0.41$ & $3.56 \pm 0.46$ & $3.32 \pm 0.40$ \\
\hline Friability (\%) & 0.65 & 0.71 & 0.73 & 0.70 & 0.73 \\
\hline Weight variation & $0.399 \pm 0.02$ & $0.400 \pm 0.02$ & $0.400 \pm 0.02$ & $0.401 \pm 0.02$ & $0.400 \pm 0.02$ \\
\hline Wetting time(sec.) & 53 & 55 & 51 & 54 & 55 \\
\hline Disintegration time & 8 & 10 & 12 & 11 & 14 \\
\hline
\end{tabular}




\begin{tabular}{|l|l|l|l|l|l|}
\hline$\%$ Drug content & 92 & 90 & 93 & 86 & 88 \\
\hline
\end{tabular}

It was observed that ibuprofen tablets prepared with papaya and corn starch passes the friability test and was found to be well within acceptable limits for all the formulation. The friability test showed that the Corn starch had slightly less binding strength than that of Carica papaya starch.

Comparative Study Of In Disintegration Time And Hardness Of Marketed Product And Optimized Formulation

Table 10 Comparative Study Of In Disintegration Time And Hardness Of Marketed Product And Optimized Formulation

\begin{tabular}{|c|c|c|c|}
\hline Sr.no. & Ibuprofen tablet & Disintegration Time(min.) & Hardness $\left(\mathbf{k g} / \mathbf{c m}^{\mathbf{2}}\right)$ \\
\hline 1 & Marketed tablet & 12 & 3.68 \\
\hline 2 & Batch $\mathrm{F}_{1}$ & 8 & 3.05 \\
\hline 3 & Batch $\mathrm{F}_{2}$ & 10 & 3.12 \\
\hline 4 & Batch $\mathrm{F}_{3}$ & 12 & 3.70 \\
\hline 5 & Batch $\mathrm{F}_{4}$ & 11 & 3.56 \\
\hline 6 & Batch $\mathrm{F}_{5}$ & 14 & 3.32 \\
\hline
\end{tabular}

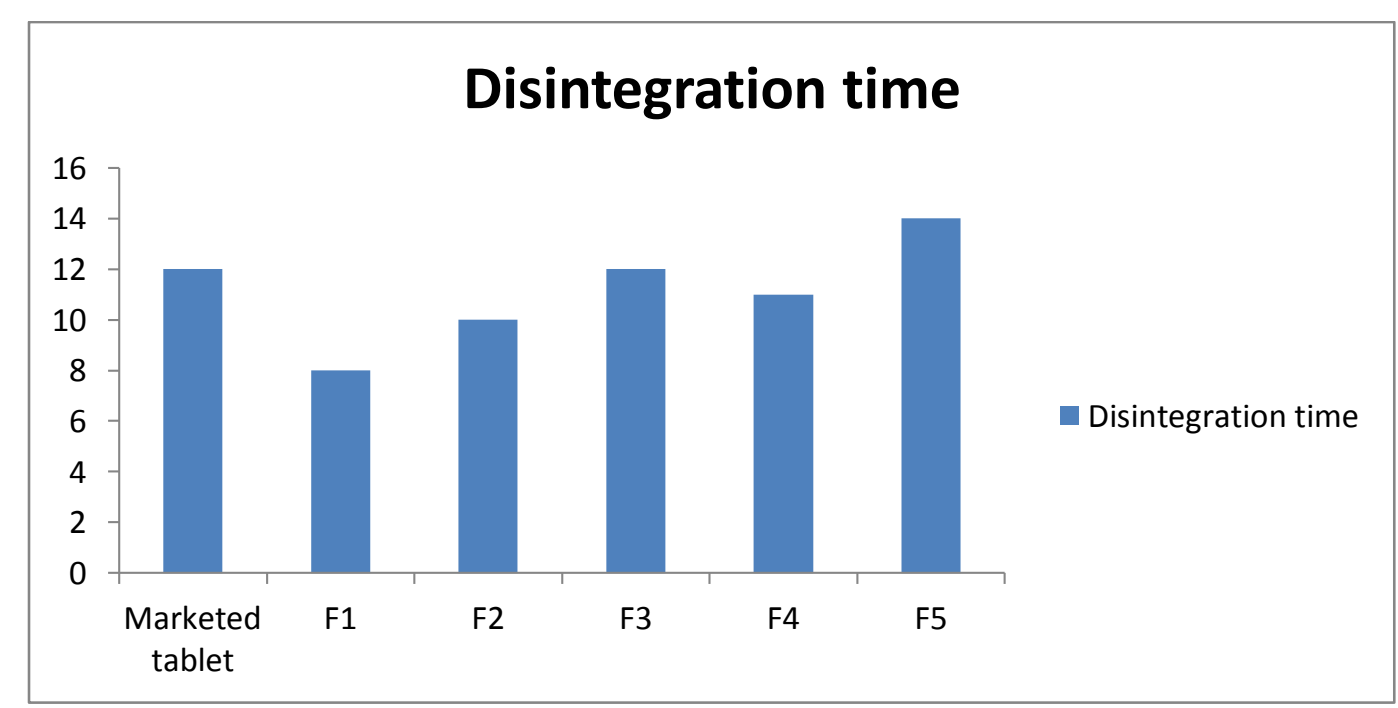

7 Comparative Disintegration time marketed tablet and formulation

Fig. - 


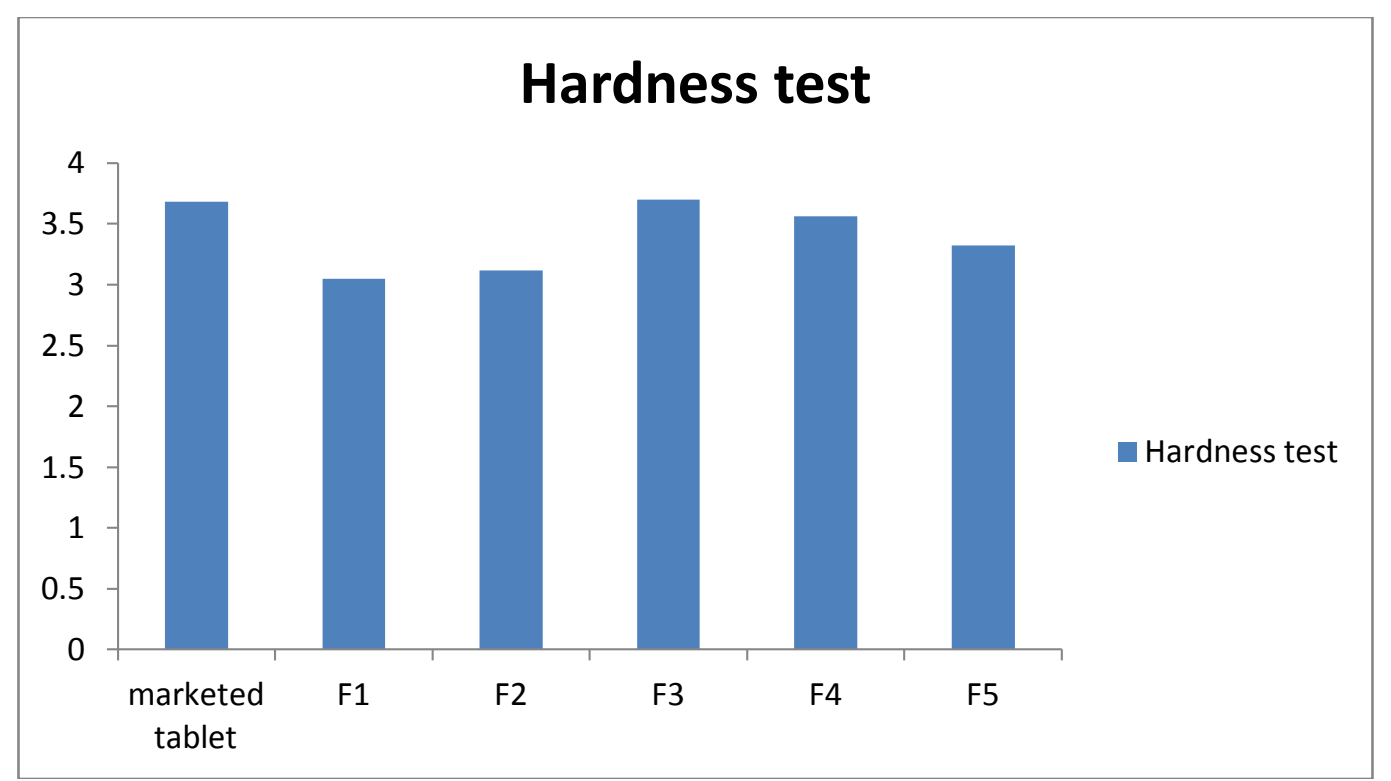

Fig. - 8 Comparative study of hardness test

Disintegration time observed was less with papaya starch at all the concentrations employed compared to those of corn starch which may be due to higher swelling capacity subjected to good disintegration property of Carica papaya. The study of disintegrating property of all the formulations showed that the disintegration time for the tablets prepared with Carica papaya was less than that of Corn starch (Table 10) reflecting its good disintegrating characteristic.

Table no. 11 Dissolution of marketed product and Prepared formulation $\mathbf{F}_{1}$

\begin{tabular}{|c|c|c|c|}
\hline Sr. no & Time (Min) & Marketed Product & $\mathbf{F}_{\mathbf{1}}$ \\
\hline 1 & 5 & 75 & 81 \\
\hline 2 & 10 & 80.2 & 84 \\
\hline 3 & 15 & 82.44 & 86 \\
\hline 4 & 20 & 86.21 & 90 \\
\hline 5 & 25 & 88 & 91 \\
\hline 6 & 30 & 90 & 92 \\
\hline 7 & 40 & 92 & 92 \\
\hline
\end{tabular}

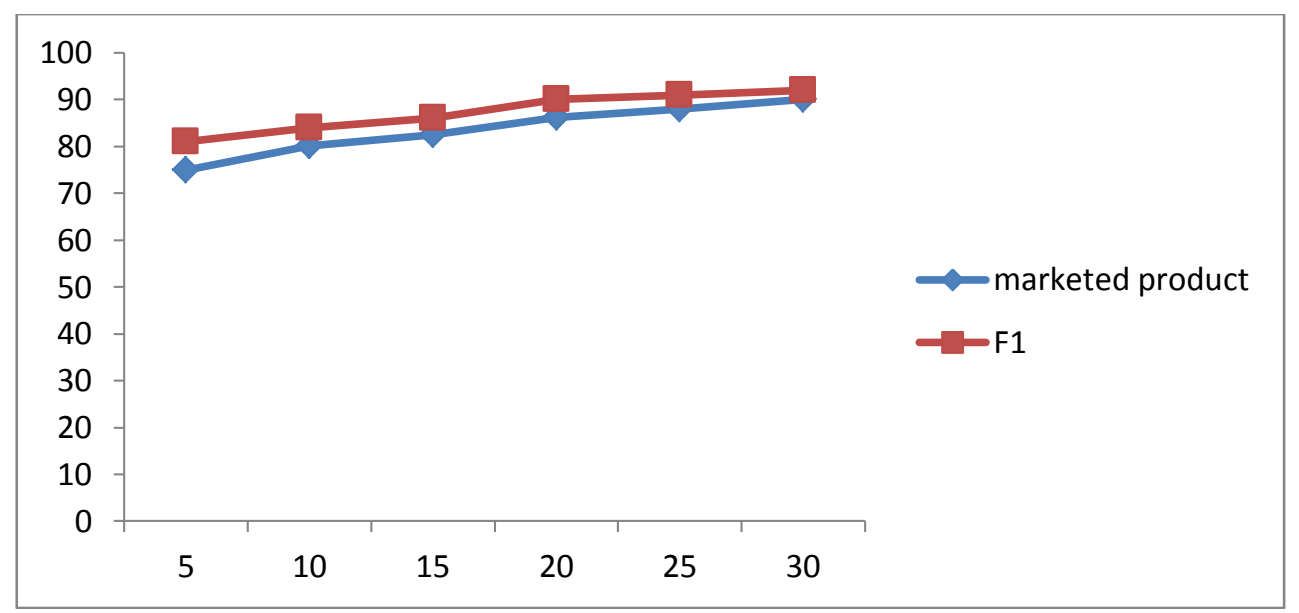

Fig. - 9 compared study of marketed tablet and prepared formulation 


\section{Conclusion:-}

The study provide some insights into the relative effectiveness of papaya starch as disintegrating agent over corn starch In addition to this it is observed that it maintains mechanical strength of a tablet in terms of friability and hardness. The dissolution studies suggest that tablets (batch F1) containing 10\% Carica papayastarch gives $92 \%$ of drug release after specified dissolution test time. Thus it can be concluded that the starch isolated from unripe papaya fruit possesses significant disintegrating properties and will excellent scope as disintegrant in pharmaceutical formulations. Papaya starch can used as a promising pharmaceutical excipient in tablet technology as, it will be show adequate physicochemical and disintegrating properties.

\section{Acknowledgement:-}

I am grateful to Dr. P.K. Dubey (Principle of SVCP Indore) for providing all the research facilities, I am highly thankful to Dr. ShikhaAgarwal for the support and completion for this work. And also thank full to BM College of pharmaceutical Edu. \& Res.

\section{References:-}

1. Indian pharmacopoeia., 1996 vol.-II, Government of India Ministry of health \& family welfare, Published by The controller of publication, Delhi.328.

2. Attama AA, Adikwu MU., "Physicochemical properties of starch derived from tacca involucrate". Nig. J. Nat. Prod. And Med. 1999; 3: 71-73

3. Verma PRP, Razdan B., "Evaluation of Leucaenaleucocephala seed gum in tabletting I. Binding properties in granules and tablets". STP Pharma Sci. 2002; 12: 113-9

4. Lachman, H.A. Lieberman and J.L Kanig. "The Theory and Practice of Industrial Pharmacy", Third edition Lea and Fibiger, Philadelphia. 1990; 296-303: 336-342.

5. Jain N.K., "Pharmaceutical product development “, 2006 first edition, published by satishkumarjain and produced by V.K. jain for CBS publisher and distributers Pvt. Ltd New Delhi, 61-111.

6. Williams David, A. and Lemke Thomas L., "Faye's principle of medicinal chemistry “, Fifth edition Reprint 2006, pub. By wolterskluwer (India) pvt. Ltd. New Delhi, 776.

7. Oloyede O.I,. "Chemical Profile of Unripe Pulp of Carica papaya". Pakistan Journal of Nutrition 2005; 4(6): 379-381.

8. Khunkitti W, Aromdee C, Vorarat S, Chitropas P. "The potential of jackfruit starch for use as suspending agent and emulsifying agent". Songklanakarin J. Sci. Technol. 2006; 28: 145-55

9. Datta R, Bandyopadhyay AK." A new nasal drug delivery system for diazepam using natural mucoadhesive polysaccharide obtained from tamarind seeds". Saudi Pharm. J. 2006; 14: 115.

10. Alebiowu, G., "Steeping period influence on physical, compressional and mechanical properties of tapioca starch J", Pharm. Res, 2007; 6, 139-144.

11. Krishna K.I., Paridhavi M, Patel J.A. "Review on Nutritional, medicinal and Pharmacological properties of Papaya (Carica papaya Linn.)". Natural Product Radiance. 2008; 7(4):364-73.

12. Tripathi, K.D., In: "Essentials of medical pharmacology", $20086^{\text {th }}$ edition. JAYPEE Brother medical publishers Ltd. New Delhi, 194.

13. Kluwers Lippincott Williams, \& Wilkins Philadelphia., 2008; 148-50: 227-259.

14. Kumar, R.; Patil, M.B.; Patil, S.R.; et al." Evaluation of Anacardiumoccidentale gum as gelling agent in aceclofenac gel". Int. J. PharmTech Res. 2009; 1: 695-704.

15. Pal D, Nayak AK, Kalia S., "Studies on Basellaalba L. leaves mucilage: Evaluation of suspending properties". Int. J. Drug Discov. Technol. 2010; 1: 15-20.

16. Odeniyi, M.A., Onu R.N., Adetunji O.A." Evaluation of bioadhesive properties of natural and modified banana starches". E Central African Journal of Pharmaceutical Sciences. 2011; 14: 34-42.

17. Nayak, AK, Pal D, Pradhan J, Ghorai T." The potential of Trigonellafoenum-graecum L. seed mucilage as suspending agent”. Indian J. Pharm. Educ. Res. 2012; 46, 312-7.

18. Arunraj, R., Comparative evaluation of potato starch and banana powder as disintegrating agents in aceclofenac tablet formulation International Journal of Pharmacy and Pharmaceutical Sciences. 2013; 5(2):204-207.

19. Remya, K.S., Beena P., Bijesh P.V., Sheeba A. "Formulation development, evaluation and comparative study of effects of super" www.iajpr.com Page9189Vol 3, Issue 11, 2013. Puri A. V et. al. ISSN NO: 2231-6876 .

20. Ahuja M, Kumar S, Kumar A., "Evaluation of mucoadhesive potential of gum cordia, an anionic polysaccharide". Int. J. Biol. Macromol. 2013; 55: 109-12. 